\title{
MONITORING OF THE FOREST EVOLUTION IN REMNANTS OF THE ATLANTIC FOREST BIOME USING RAPIDEYE IMAGERY
}

Monitoramento da evolução florestal em remanescentes do bioma Mata Atlantica utilizando imagens RapidEye

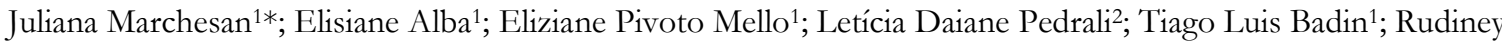 \\ Soares Pereira ${ }^{3}$ \\ ${ }^{1}$ Postgraduate Program in Forestry Engineering; Federal University of Santa Maria; *marchesan.ju@gmail.com; \\ elisianealba@gmail.com; elizianemello@yahoo.com.br; eng.tiagobadin@gmail.com \\ * Author for correspondence \\ ${ }^{2}$ Master in Forestry Engineering; Federal University of Santa Maria; lelepedrali@gmail.com \\ ${ }^{3}$ Department of Rural Engineering, Federal University of Santa Maria; rudiney.s.pereira@gmail.com
}

Artigo enviado em 26/04/2017, aceito em 12/12/2017 e publicado em 10/04/2018.

\begin{abstract}
This study aimed towards analyzing the space-time evolution of the forest covering of the Atlantic Forest biome in extremely high priority area for the preservation of biodiversity located in the central region of Rio Grande do Sul, between the years of 2011 and 2013. The mapping of land use and land cover was accomplished by means of the Bhattacharya supervised assortment, utilizing RapidEye/REIS imagery in the years of 2011 and 2013, the kappa coefficient was used to analyze the quality of the classification. The spatialization of the forest dinamics was accomplished by identifying the upkeep, expansion and deforestation areas during the analysis period. For the years 2011 and 2013 a Kappa index of 0.88 and 0.87 was obtained, respectively. The agriculture presented the highest evolution percentage, presenting an $11.89 \%$ increase, whereas the forest coverage presented a $8.21 \%$ decrease. The evolutionary analysis of the forest coverage demonstrated that the forest deforestation was of $6.31 \%$ and the expansion of native forests was of $4.30 \%$. The spatial analysis presented high potential on identifying alteration spots of the Atlantic Forest Bioma's natural vegetation in large scale. Therefore, this tool can be used along with the policies of preservation of the natural ecosystems.
\end{abstract}

Keywords - Forest cover. Deforestation. Landscape study. Geoprocessing.

Resumo - Esse estudo objetivou analisar a evolução espaço temporal da cobertura florestal do bioma Mata Atlântica em área de prioridade extremamente alta para a conservação da biodiversidade situados na região central do Rio Grande do Sul, entre os anos de 2011 e 2013. O mapeamento do uso e cobertura da terra foi realizado por meio da classificação supervisionada Bhattacharya, utilizando imagens RapidEye/REIS nos anos de 2011 e 2013, o coeficiente kappa foi utilizado para analisar a qualidade da classificação. A espacialização da dinâmica florestal foi realizada identificando as áreas de manutenção, expansão e desmatamento no período de análise. Para os anos de 2011 e 2013 obteve-se um índice Kappa de 0,88 e 0,87, respectivamente. A agricultura apresentou o maior percentual de evolução, expressando um aumento de $11,89 \%$, enquanto que a cobertura florestal teve uma redução de $8,21 \%$. A análise evolutiva da cobertura florestal demonstrou que o desmatamento foi de $6,31 \%$ e a expansão das florestas nativas de 4,30\%. A análise espacial demonstrou grande potencial em identificar pontos de alteração da vegetação natural do Bioma Mata Atlântica em diferentes escalas. Assim, essa ferramenta pode ser utilizada junto as políticas de conservação dos ecossistemas naturais.

Palavras-Chave - Cobertura florestal. Desmatamento. Estudo da paisagem. Geoprocessamento.

\section{INTRODUCTION}

The predatory action in the Atlantic Forest biome has been performed since the XVI century (NEVES, 2006). The exploitation of natural resources has allowed the increase of agriculture, extractivism, extensive raising of livestock and urban expansion
(BACHA, 2004). In the Atlantic Forest biome the deforestation has happened for many years, currently being verified scarcity of preserved areas, which makes it one of the most threatened biomes (NEVES, 2006).

Seeking to minimize the damage related to the impact caused by the extraction of natural resources, in 
the year of 1965 the Law $n^{\circ} 4,771$ amended by Law $n^{\circ}$ $12,651 / 2012$ was put into effect, known as the Brazilian Forest Code, in which the use of forests was restricted by means of establishing Legal Reserve Area and the Permanent Preservation Area (BRASIL, 2012). Soon afterwards, along with the promulgation of the Federal Constitution of 1988, the Atlantic Forest went on for being considered as national treasure, and its use to be restrained within conditions that assured the preservation of the environment, including the use of natural resources (BRASIL, 1998). According to Silveira (1998) that was an attempt to conciliate individual and collective interests, demonstrating the social function against the right to property.

In the past 18 years alone the Atlantic Forest has lost circa $18,509 \mathrm{~km}^{2}$ of its area, and is currently under critical conditions, being considered the most threatened by extinction of the Brazilian biomes, with only $12.5 \%$ of its original area remaining (1.3 million $\mathrm{km}^{2}$ ) (SOS MATA ATLANTICA, 2014). The original area of that ecosystem corresponded to circa $16 \%$ of the Brazilian territory and was present in 17 states of the southern, southeastern, midwestern and northeastern regions (NEVES, 2006), that goes to show the dimension of the loss in those forests. According to Ribeiro et al. (2009) most of that forest is in secondary and highly fragmented remnants, being that $83 \%$ of the remnants are under 50 ha.

In that context, the satellite images provide an analysis on the dynamics of the landscape through the course of temporal series, being of great relevance on the monitoring of the vegetation aiming the preservation of the natural resources. Plenty of studies have been successfully relating the spatial data with the landscape dynamics, as it allows to identify and quantify the changes in the land use and land cover of the land (DESSBESELL et al., 2015; SOS MATA ATLANTICA, 2014), as well as their relation to the environmental variables (TRENTIN et al., 2015).

The Atlantic Forest holds a classification imposed by the Ministry of Environment, according to the preservation's priority of the biodiversity, divided in: high, very high and extremely high. The present work considered the basin Arroio Pessegueiro, which represents an extremely high priority area of preservation within the Atlantic Forest biome. In addition to the constant need for conservation of ecosystems, the study area expresses relevance from the monitoring point of view of its evolution of the forest cover and, consequently, to evaluate if the environmental conditions of the area are ensuring the preservation of its biodiversity.

In that context, the present work aims to analyze the space-time evolution of the forest coverage of the Atlantic Forest biome in areas of extremely high priority for preservation of the biodiversity, located in the state of Rio Grande do Sul, between the years of 2011 and 2013, by means of RapidEye/REIS imagery.

\section{MATERIAL AND METHODS}

The study area consists of the basin Arroio Pessegueiro, encompassing parts of the Jaguari and Jari counties in the state of Rio Grande do Sul, Brazil. That basin represents an area of 9,667.63 ha, located among the coordinates of $54^{\circ} 21^{\prime} 11.50^{\prime \prime}$ and $54^{\circ} 31^{\prime} 36.30^{\prime \prime}$ west longitude and $29^{\circ} 22^{\prime} 57.03^{\prime \prime}$ and $29^{\circ} 28^{\prime} 33.05^{\prime \prime}$ south latitude (Figure 1). The study area is located within the Atlantic Forest biome, corresponding to a high protection fragment, once it is part of the areas of extremely high priority for preservation and allocation of benefits of the biodiversity if the Atlantic Forest biome (MMA, 2007).

The basin is formed by the stationary deciduous forest, having as its substracts the Serra Geral geological formations, composed of basaslt, the Botucatu, composed of aeolian sandstone (PINHEIRO and DIAS, 1995; CORDEIRO and HASENACK, 2009; SANTOS, 2010). The regions climate, according to Koppens classification, is denominated as Cfa, humid subtropical, with hot summers and mild winters (ALVARES et al., 2014). According to the IBGE (2014), the study area is characterized by the agricultural and livestock production based economy. The temporary crops of higher importance consist of crops of soy, rice and corn. The bovine livestock is of great importance to that region, playing considerable part of the economy.

The creation of the database and the processing of the imagery were performed in SPRING (Georeferenced Information Processing System), in the 5.2.1 version (CÂMARA et al., 1996). It was adopted for the present work LATLONG cylindrical cartographic projection and WGS-1984 (World Geodetic System 1984) reference Datum.

Digital imagery from the REIS sensor (RapidEye Earth Imaging System) was used, with 12 bit radiometry, spatial resolution of 5 meters, due to the orthorectification of the images which is characterized as a preprocessing technique, which allowed recognition of features located on the ground surface equal to or greater than $25 \mathrm{~m}^{2}$. These images are dated from September and December of the years 2011 and 2013. They were given from the project of the Federal University of Santa Maria in partnership with the Interstate Union of the Tobacco Industry (SINDITABACO). 


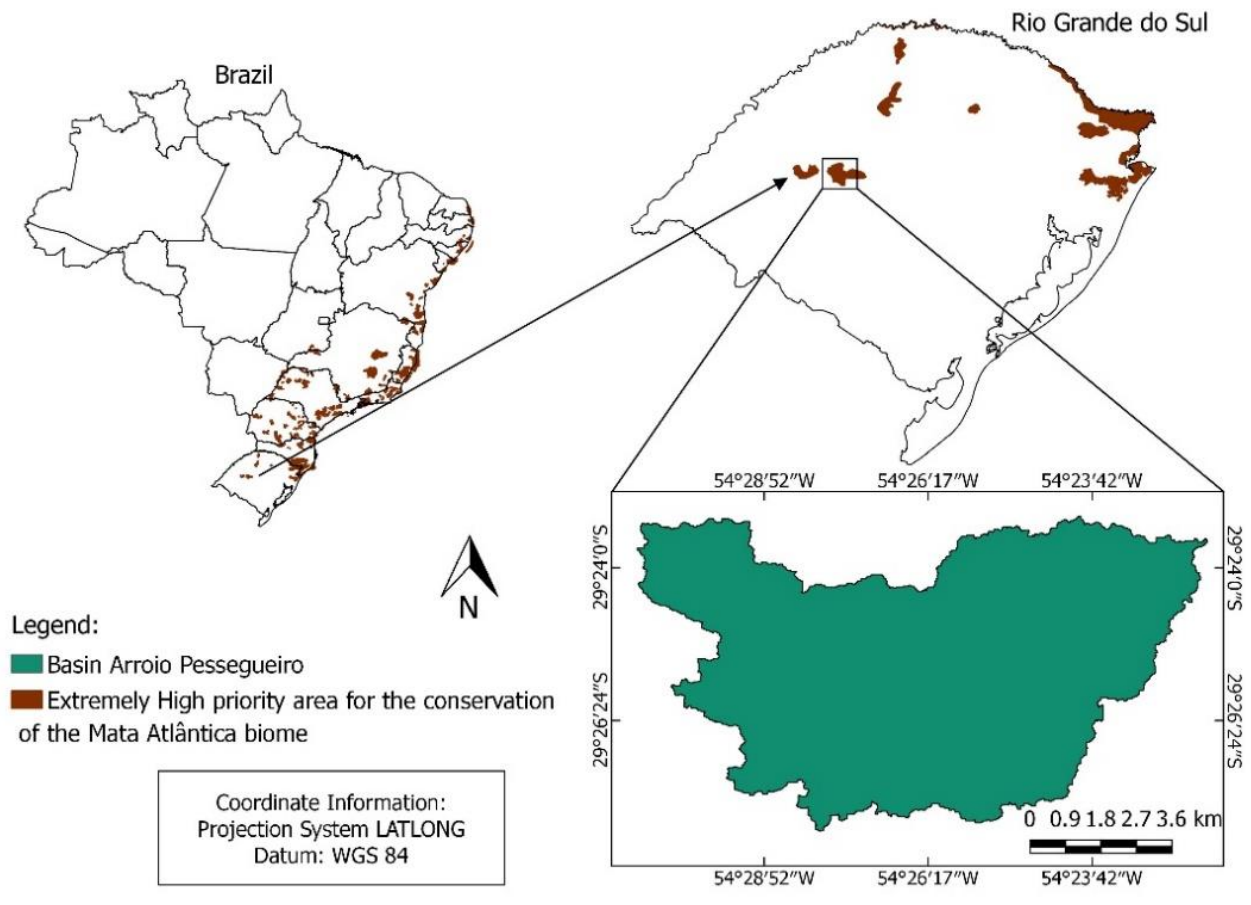

Figure 1. Location of the study area

Segmentation, a process that precedes classification, has the purpose of dividing the image into regions that correspond to objects of work interest, so regions are grouped or divided depending on whether the pixels in the image have similar characteristics in terms of shape, texture or color (HAPP et al., 2013). Among the segmentation techniques, the regions growth method was chosen, which consists of aggregating neighboring pixels to a specific sub region that has similar characteristics, thereby increasing the regions (HAPP et al., 2013). For this, the parameters of similarity must be established, which is based on statistical tests to verify the average between regions being possible to define if they will be joined or separated according to the values of gray, and the area, that represents the minimum number of pixels in each region (INPE, 2006). Thus, a labeled image is generated, which is used in the classification process. The images were segmented with the similarity standards and area of 100 and 10, respectively, since these better parameters fit the study area.

The supervised digital classification was performed by the classifying algorithm Bhattacharya, with an acceptance threshold of $99 \%$. The classifier Bhattacharya consists of a supervised classification algorithm, which requires selection of training areas, then evaluates each region the distance of Bhattacharya (Euclidean Distance) between classes in order to measure the separability of a pair of classes
(MOREIRA, 2005). In Which six thematic classes were identified and mapped: Native Forest, composed of remnants of native forest belonging to the Atlantic Forest; Planted Forest, comprising forestry area with predominance of eucalyptus and pine plantations; Field, covering natural grassland areas; Agriculture, consisting of areas with plantations where there is vegetation cover; Exposed Soil, including agricultural areas without vegetation and areas fallow or in preparation for planting; and Water, including rivers, lakes, ponds and bathed areas.

The reliability of the mapping performed for the two study dates was verified by the Kappa coefficient proposed by Cohen (1960), following the methodology described by Congalton (1991). The quality of the generated data was evaluated according to the limits proposed by Landis and Koch (1977), as demonstrated in the Table 1. For the calculation, used 300 randomly distributed stratified points, being 50 points in each class of land use and land cover. It was decided to use this number of points based on Congalton's methodology (1991), which suggested the minimum size of 50 samples for each class in areas with territorial coverage of up to approximately 4,050 $\mathrm{km}^{2}$. In order to verify the accuracy of the classification, the images of the REIS sensor were used, as well as images of Google Earth Pro TM (Google Inc., 2016) dated December 2011 and 2013 


\begin{tabular}{l} 
Corresponding to the years of the REIS images in ord \\
to be consistent with the images classified. \\
Table 1. Classification quality according to intervals \\
the Kappa coefficient \\
$\begin{array}{rc}\text { Kappa value } & \text { Classification } \\
\text { quality }\end{array}$ \\
$\begin{array}{rc}<0.00 & \text { Very bad } \\
0.00-0.20 & \text { Bad } \\
0.40-0.40 & \text { Acceptable } \\
0.60-0.80 & \text { Good } \\
0.80-1.00 & \text { Very good } \\
\text { Excellent }\end{array}$ \\
\hline
\end{tabular}

Source: Landis and Koch (1977)

For the analysis of the native forest dynamics to be possible in the study period a crossing of the data was made, using in this study maps of land use and land cover in the years of 2011 and 2013. For this, it was carry out the intersection of thematic with the aid of LEGAL (Spatial Language for Algebraic
REVISTA SCIENTIA AGRARIA

Versão On-line ISSN 1983-2443

Versão Impressa ISSN 1519-1125

SA vol. 19 n $^{\circ} .1$ Curitiba Jan/Mar 2018 p. 43-51
Geoprocessing) program available in SPRING. For such, three thematic classes were created, designated as Forest Maintenance, Forest Expansion and Forest Deforestation class nomenclature was defined to encompass the dynamics of the native forest cover present in the study area. Forest Maintenance corresponds to areas of native forest present in the year 2011 that remained unaltered by the year 2013; Forest Expansion refers to native forest areas present in areas that were previously occupied by the other thematic classes; Forest Deforestation corresponds to areas of native forest that in the 2013 image were converted to other thematic classes.

\section{RESULTS AND DISCUSSION}

The monitoring of remnant fragments of the Atlantic Forest biome in extremely high priority of preservation areas in the central region of the state of Rio Grande do Sul. During the period of 2011 and 2013, was obtained by means of classification of land use and land cover. In the Figure 2 and 3 it is possible to analyze the evolution of the landscape in the timeframe in analysis.

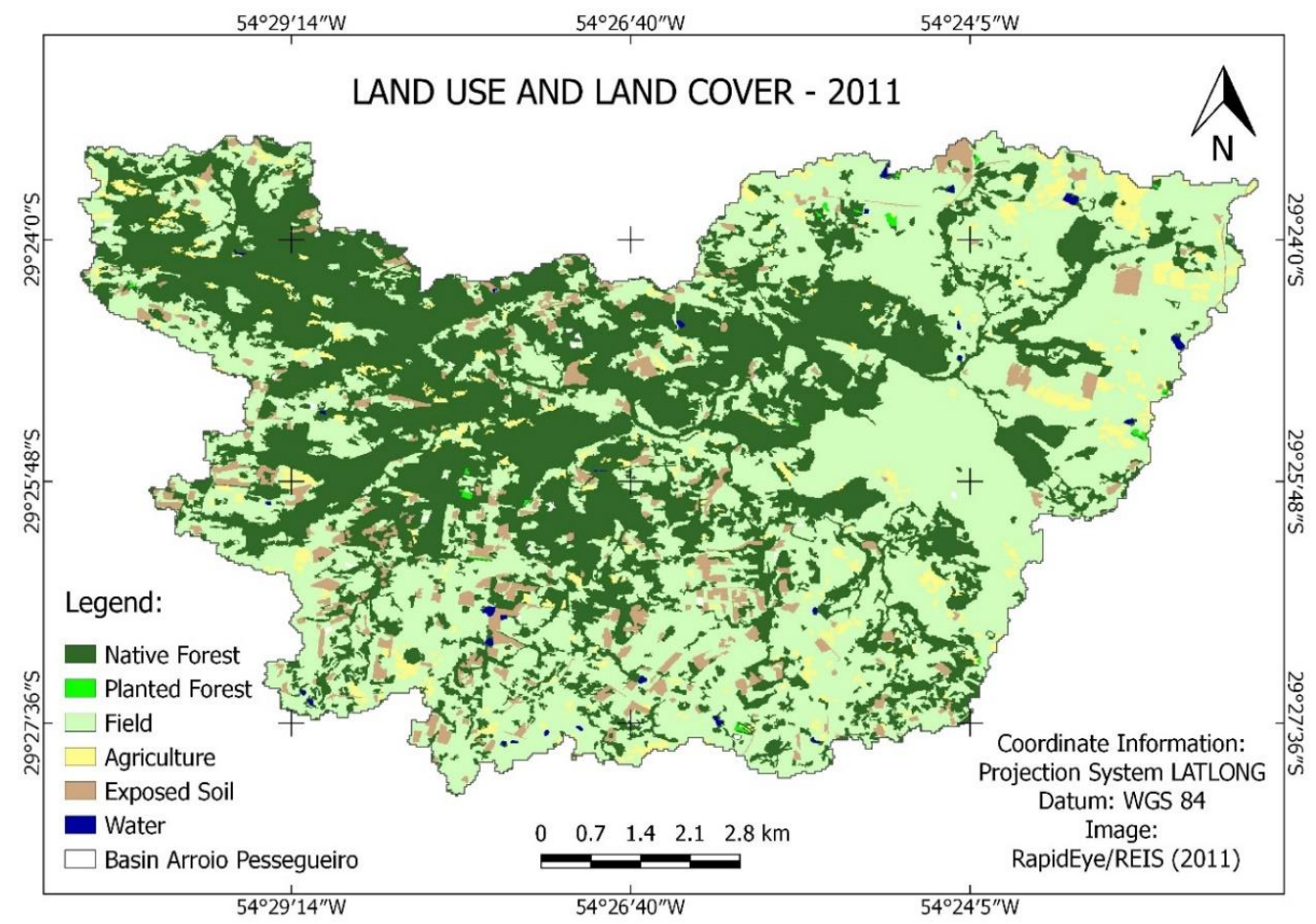

Figure 2. Mapping of the land use and land cover in 2011 


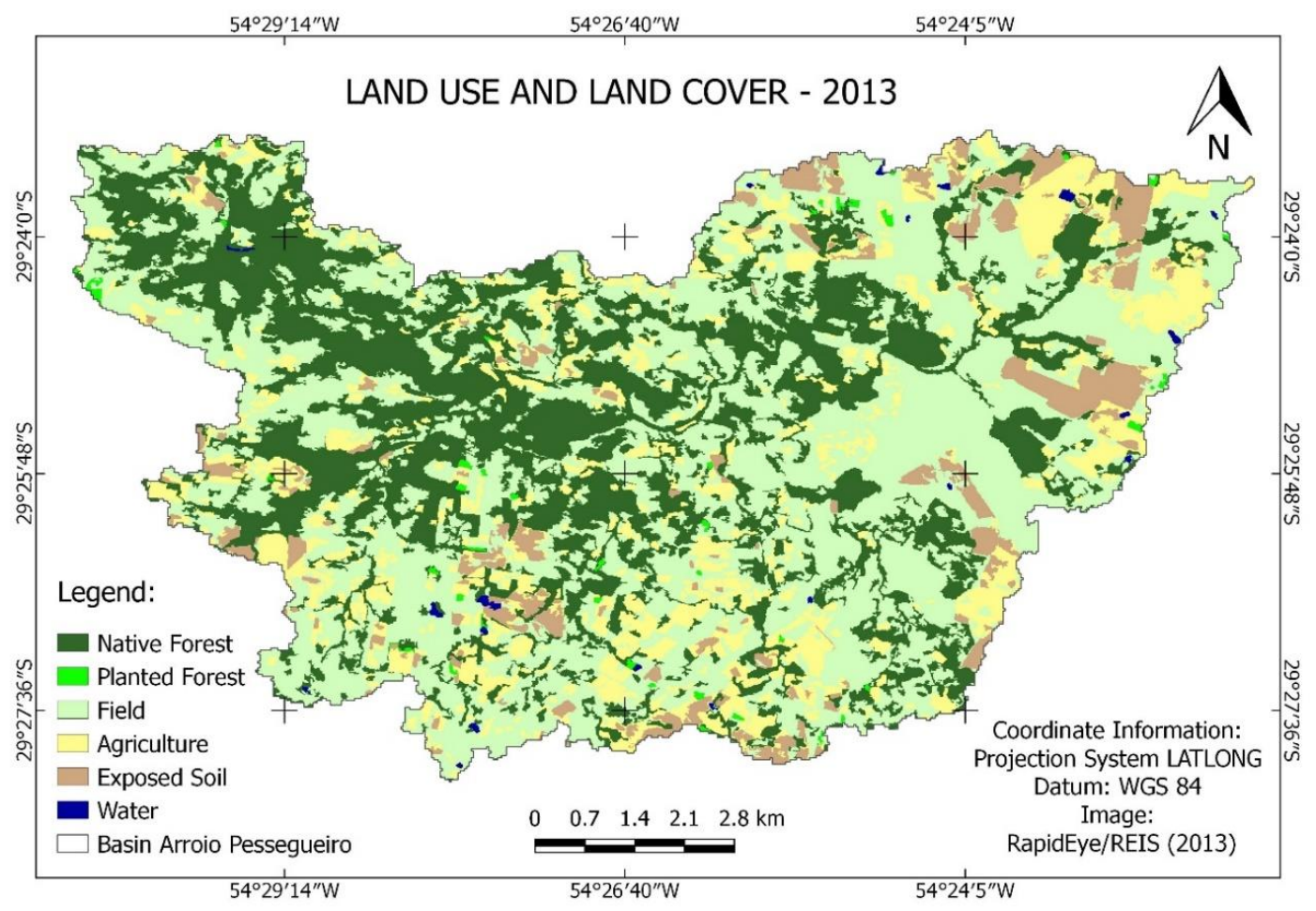

Figure 3. Mapping of the land use and land cover in 2013

The quality of the supervised classification accomplished for the years of 2011 and 2013, following the limits presented in the Table 1, was considered to be "excellent", presenting Kappa coefficients in the value of $0.88(88.00 \%)$ and $0.87(87.00 \%)$, respectively, obtained using 50 points randomly distributed in each class of land use and land cover. Thus, the values found are considered high, indicating a small classification error for both study dates, and it is possible to count with confidence the changes occurring in the basin.

The study area located within the Atlantic Forest biome is characterized by presenting rough terrain, therefore the classes of land use and land cover were conditioned regarding to its relief. In that condition, in flat areas the predominance of agriculture and field was observed, whereas the native forest occurs, for the most part, associated with the sloping areas and the courses of the rivers.

These results corroborate with that described by Caneppele et al. (2017) under study in the region. The authors portray that the sloping areas are not suitable for mechanized agriculture and today they do not receive manual practices such as the brushing that allowed the cultivation in these areas formerly. Thus, there was an abandonment of the rudimentary practices and consequently of the cultivated areas in these places, in this way, there was an increase of native forest in sloping areas in the last decade.

The quantitative analysis of the mapping of the land use and land cover is exposed in the Table 2. Which demonstrated predominance of the field and native forest classes, respectively, in both dates studied. Therefore, in 2011 the area occupied by field represented $4,912.21$ ha, equivalent to $50.81 \%$ of the total of the hydrographic basin, whereas the native forest occupied 3,886.21 ha, which corresponds to $40.20 \%$ of the studied area.

In 2013 these percentages remained similar, although the native forest area was reduced in $8.21 \%$, going on to occupy $3,096.43$ ha or $31.99 \%$ of the total area, evidencing the advancement of the other usage classes under areas of native forest. The field class presented losses in the year 2013 in comparison to its accounted area in 2011, that being of $5.55 \%$, reducing its occupation to $4,380.22$ ha, equivalent to $45.25 \%$ of the total. The planted forest presented a different behavior from the one described above, demonstrating its growth. In 2011 the forest planted occupied 11.72 ha, equivalent to $0.12 \%$ of the total area, however in 2013 that class went on to correspond to 42.19 ha or $0.44 \%$ of the area of the hydrographic basin. 
Table 2. Quantitative analysis of the area occupied by the thematic classes in the years 2011 and 2013

\begin{tabular}{lrrrrrr}
\hline \multirow{2}{*}{$\begin{array}{c}\text { Land use and } \\
\text { land cover }\end{array}$} & \multicolumn{2}{c}{ Area in 2011* } & \multicolumn{2}{c}{ Area in 2013* } & \multicolumn{2}{c}{ Difference (Area) } \\
\cline { 2 - 7 } & \multicolumn{1}{c}{ ha } & \multicolumn{1}{c}{$\boldsymbol{\%}$} & \multicolumn{1}{c}{ ha } & \% & \multicolumn{1}{c}{ ha } & \% \\
\hline Native Forest & $3,886.21$ & 40.20 & $3,096.43$ & 31.99 & -789.78 & -8.21 \\
Planted Forest & 11.72 & 0.12 & 42.19 & 0.44 & 30.47 & 0.31 \\
Field & $4,912.21$ & 50.81 & $4,380.22$ & 45.25 & -531.99 & -5.55 \\
Agriculture & 364.65 & 3.77 & $1,516.29$ & 15.67 & $1,151.64$ & 11.89 \\
Exposed Soil & 472.55 & 4.89 & 619.40 & 6.40 & 146.85 & 1.52 \\
Water & 20.27 & 0.21 & 24.02 & 0.25 & 3.75 & 0.04 \\
\hline
\end{tabular}

*Kappa coefficient $0.88(88.00 \%)$ and $0.87(87.00 \%)$ in 2011 and 2013 , respectively.

Among the classes of land use and land cover, agriculture stood out for presenting the higher percentage of transition in the analyzed timeframe, presenting and expansion of 1,151.64 ha, equivalent to $11.89 \%$. That dynamics of landscape alteration is aligned to the practices of land tillage, that way the IBGE (2014) defines the studied region as essentially agricultural, producing mostly soy, corn, rice, wheat and tobacco.

The exposed soil, characterized by fallow agricultural areas and in preparation for plantations, occupied an area of 472.55 ha in 2011 increasing in 2013 to 619.40 ha. This class is associated with agriculture differing only because there is no vegetation cover at the moment of image collection. Thus, in 2013, 2,135.69 ha of agricultural areas were added (including exposed soil and agriculture), which correspond to $22.07 \%$ of the study area.

With land use and land cover mapping, it was possible to infer that, during the study years, there was a trend in class changes, in which there was a decrease in native forest and in the countryside, concomitantly with the increase in the areas occupied by agriculture, probably, are expanding in areas of native vegetation. This expansion is occurring in flat areas, which are favorable to agricultural plantations (CANEPPELE et al., 2017).

This results obtained in the present study corroborate with the data of agricultural production made available by the IBGE (2014), which demonstrates that region of the Atlantic Forest biome presenting an increase of the agricultural production in the timeframe of 2011 to 2013 of $3.23 \%$. Due to the fact that the region economy is aimed towards agriculture, there is a great interest in the expansion of those areas, so, those usages may be implanted in improper areas and, at times, suppressing the native vegetation.

In this way, it is possible to show that the lack of Conservation Units in the study area, which is composed only of particular areas, entails the reduction of efficient measures for the preservation of forest remnants. Since, in the years of study, the suppression of the native forest was verified for the implementation of other uses, like agriculture. Mello et al. (2014) analyzed the fragments of native forest of the Atlantic Forest close to the study site, verified the increase in the number of fragments and decrease of the areas occupied by these, corroborating with the one obtained in the present study.

In that manner, the analysis of the space-time dynamics of the native forest coverage in the timeframe of 2011 to 2013, accomplished by means of crossing of the thematic maps, demonstrates the spatialization of the changes occurred in the native forest in relation to the other land use and land cover (Figure 4). This analysis becomes important in order to implement measures that minimize the impacts caused by the suppression of the native forest and still preserve the remaining remnants. In addition, it makes possible to analyze forest expansion in areas formerly occupied by other uses such as field and agriculture.

The space-time analysis of the evolution of the native forest cover demonstrated the forest maintenance represented 2,375.67 ha, corresponding to $24.55 \%$ of the total area of the hydrographic basin. The expansion of the native forest cover in the timeframe of 2011 to 2013 was of 415.9 ha, therefore the native forest expansion represented $4.30 \%$ of the studied area (Table 3). 


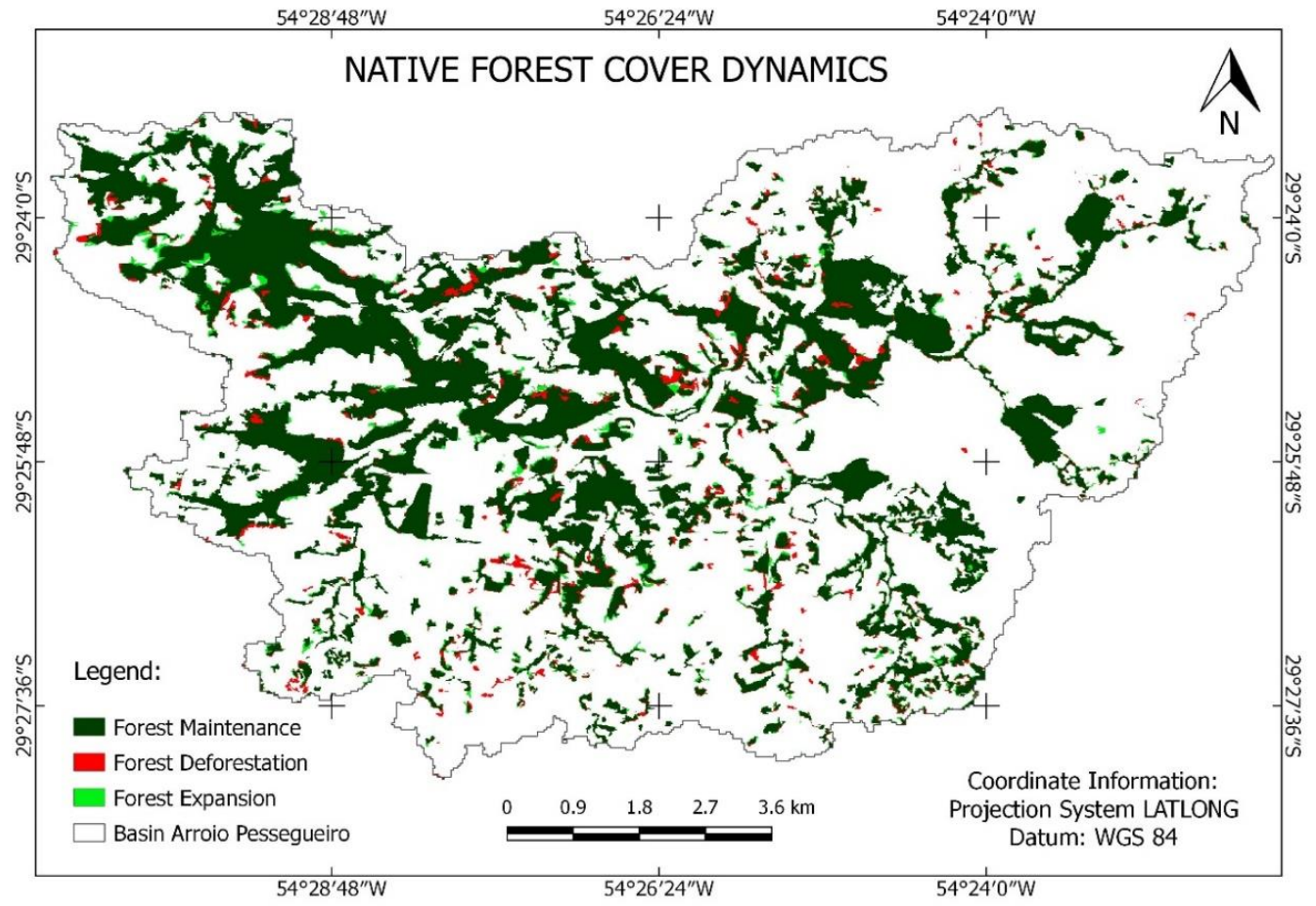

Figure 4. Space-time dynamics of the native forest cover of fragments of the Atlantic Forest biome in areas of extremely high priority of environmental preservation in the period of 2011 and 2013

Table 3. Quantitative analysis of the space-time dynamics of the native forest cover in the 2011 and 2013 period

\begin{tabular}{lrr}
\hline \multirow{2}{*}{ Native Forest Dynamics } & \multicolumn{2}{c}{ Area } \\
\cline { 2 - 3 } & \multicolumn{1}{c}{ ha } & \multicolumn{1}{c}{$\%$} \\
\hline Forest Maintenance & $2,375.67$ & 24.55 \\
Forest Deforestation & 610.57 & 6.31 \\
Forest Expansion & 415.90 & 4.30 \\
\hline
\end{tabular}

The Atlantic Forest biome is fragmented due to the predatory action occurred since the XVI century (NEVES, 2006). That fragmentation, as it can be observed in the Figures 2, 3 and 4, hinders the restoration and expansion process of that vegetation, since anthropogenic actions are predominant in surrounding areas, preventing the reestablishment of the native forest. In the same manner, the fragmentation can affect the local fauna, hindering the recomposition of the ecosystem structure and function of the suppressed areas.

The suppression of the native vegetation of the Atlantic Forest biome within the hydrographic basin of Arroio Pessegueiro represented a $6.31 \%$ percentage corresponding to 610.57 ha in the timeframe of 2011 to 2013 . These results demonstrated that the deforestation of the biome in the studied area continues to occur, even with the restrictions imposed by the enforced legislation.

A study developed by Neves (2006) determines that the large causes for the deforestation of the Atlantic Forest in the years of 1985 to 1996 was due to the raising of bovine livestock, reduction of the pasture areas, minor wood exploitation in logs and for the low HDI (Human Development Index) of the regions. Thus, the current scenario is a consequence of that exploitation, at times subsidized by economic incentives, aimed at the expansion of agriculture and livestock raising.

Although the expansion of the native vegetation of the Atlantic Forest biome was detected (Table 3), a higher suppression percentage was observed of the areas with native forest that was non explored thus far. Therefore, locations that presented native tree vegetation of the preserved biome are being eliminated, whereas areas already degraded by anthropic usage are being abandoned, which could allow recovery of its ecological structure and function. Thus, actions that help in the preservation and / or recovery of forest remnants are necessary in order to 
contribute to the increase of native forest cover in the region under study.

However, it should be noted that, areas composed of native forest are increasing through the process of regeneration caused, often, by the abandonment of agricultural areas or used for livestock. The same tendency was observed by Mello et al. (2015), in which the authors, when studying the changes in land use and land cover, using RapidEye / REIS images in an area close to the Arroio Pessegueiro basin, obtained results that demonstrate the expansion of the native forest in an area formerly occupied by agriculture.

The region of the Atlantic Forest biome monitored for this research is characterized by small properties and with that, a more detailed analysis of the land use and land cover might better represent the field reality, since small areas of native forest may be being suppressed. The spectral characteristic of the spatial data utilized in this study may have positively influenced, as the REIS sensor presents large capacity to detect small alterations in the terrestrial surface, registering a minimum area of $25 \mathrm{~m}^{2}$.

\section{CONCLUSIONS}

The quantitative analysis of the amounts occupied by native forest cannot be solely considered as a basis for purposes of evaluation of preservation areas occupied by the Atlantic Forest existing in the studied area, under pain of underestimating deforestation indexes. Despite the fact that the data demonstrate and increase on the total covered by that native physiognomy, the crossing of the data resulting from the spatial analysis demonstrated that there has been deforestation in native remnants.

The fact that there was regeneration of the forest, balancing the suppressed areas, does not express preservation of that biome in the region, considering that these remnants are still being suppressed, giving room to other land use and land cover. These results point out to the necessity of enforcing the policies and inspections aimed at the preservation of the biodiversity of the forest fragments and the Atlantic Forest biome as a whole, considering that the deforestations continue to occur.

\section{REFERENCES}

ALVARES, C. A.; STAPE, J. L.; SENTELHAS, P. C.; GONÇALVES, J. L. M.; SPAROVEK, G. Köppen's Climate Classification Map for Brazil. Meteorologische Zeitschrift, v. 22, n. 6, p. 711-728, 2014.
BACHA, C. J. C. O Uso de Recursos Florestais e as Políticas Econômicas Brasileiras - Uma Visão Histórica e Parcial de um Processo de Desenvolvimento. Revista de Estatística e Economia, São Paulo, v. 34, n. 2, p. 393426, 2004.

BRASIL. Lei $n^{\circ} 12.651$ de 25 de maio de 2012: Dispõe sobre a proteção da vegetação nativa. Available in: http://www.planalto.gov.br/ccivil_03/_ato2011-

2014/2012/lei/112651.htm. Accessed in: 27 nov. 2015.

BRASIL. Constituição da República Federativa do Brasil: Promulgada em 5 de outubro de 1988. 1998. Available in:

http://www.planalto.gov.br/ccivil_03/constituicao/C onstituicaoCompilado.htm. Accessed in: 27 nov. 2015.

CANEPPELE, J. C. G.; VIEIRA, L. F. S.; VERDUM. R. Áreas abandonadas e possibilidade de pagamentos por serviços ambientais em Esperança do Sul/RS. Boletim Geográfico do Rio Grande do Sul, n. 30, p. 113-138, 2017.

CÂMARA, G.; SOUZA, R. C. M.; FREITAS, U. M.; GARRIDO, J. Spring: Integrating remote sensing and GIS by object-oriented data modelling. Computers \& Graphics, v. 20, n. 3, p. 395-403, 1996.

COHEN, J. A. Coefficient of agreement for nominal scales. Journal of Educational and Measurement, v. 20, n. 1, p. 37-46, 1960.

CONGALTON, R. G. A review of assessing the accuracy of classifications of remotely sensed data. Remote Sensing of Environment, v. 37, n.1, p. 35-46, 1991.

CORDEIRO, J. L. P.; HASENACK, H. Cobertura vegetal atual do Rio Grande do Sul. In: PILLAR, V. de. P; MÜlleR, S. C.; CASTILHOS, Z. M. de S.; JACQUES, A. V. A. (Ed.). Campos Sulinos: conservação e uso sustentável da biodiversidade. Brasília: Ministério do Meio Ambiente, 2009. cap. 23, p. 285-299.

DESSBESELL, L.; PEREIRA, R. S.; FARIAS, J. A.; VOGT, E. A.; WELTER, C. A. Classificação do uso e cobertura da terra a partir de imagens RapidEye para o município de Segredo - RS - Brasil. Geografia, v. 40, n. 2, p. 291-304, mai./ago. 2015.

Google - Inc. Google Earth. Available in: https://www.google.com/earth/. Accessed in: 20 abr. 2017. 
HAPP, P. N.; FEITOSA, R. Q.; BENTES, C.; FARIAS, R. Um algoritmo de segmentação por crescimento de regiões para GPUS. Boletim de Ciências Geodésicas, v. 19, n. 2, p. 208-226, abr./jun. 2013.

IBGE. Instituto Brasileiro de Geografia e Estatística. Produção agrícola municipal: lavoura temporária. Available in:

http://cidades.ibge.gov.br/xtras/perfil.php?lang=\&co dmun $=431110$. Accessed in: 03 abr. 2016.

INPE. Instituto Nacional de Pesquisas Espaciais. Segmentação de Imagens. 2006. Available in: http://www.dpi.inpe.br/spring/portugues/tutorial/seg mentacao.html. Accessed in: 18 out. 2017.

LANDIS, J.; KOCH, G. G. The measurements of agreement for categorical data. Biometrics, Washington, v. 33, n. 3, p. 159-179, 1977.

MELLO, E. P.; PEREIRA, R. S.; ARAÚJO, E.; TRAMONTINA, J.; ALBA, E.; SILVA, P. S. B. da.; ZANIN, E. M. Estudo da evolução da fragmentação em Floresta Estacional Decidual após 22 anos utilizando métricas de paisagem. In: SIMPÓSIO BRASILEIRO DE PÓS-GRADUAÇÃO EM CIENCIAS FLORESTAIS, 8., 2014, Recife. Anais... Recife: Universidade Federal de Pernambuco, 2014.

MELLO, E. P.; PEREIRA, R. S.; ALBA, E.; TRAMONTINA, J.; ARAÚJO, E.; PEDRALI, L. D.; SILVA, P. S. B. da. Análise evolutiva da dinâmica florestal nativa por meio da Linguagem de Geoprocessamento Algébrico, utilizando imagens de alta resolução espacial do sensor REIS. In: SIMPÓSIO BRASILEIRO DE SENSORIAMENTO REMOTO, 16., 2015, João Pessoa. Anais... São José dos Campo: INPE, 2015.

MMA. Ministério do Meio Ambiente. Áreas prioritárias para a conservação, uso sustentável e repartição de benefícios da biodiversidade brasileira: Atualização - Portaria MMA n09, de 23 de janeiro de 2007. Available in: http://www.mma.gov.br/estruturas/chm/_arquivos/b iodiversidade31.pdf. Accessed in: 10 april. 2017.

MOREIRA, M. A. Fundamentos do sensoriamento remoto e metodologias de aplicação. 3. ed. Viçosa: Ed. UFV, 2005. 320 p.
NEVES, A. C. M. Determinantes do desmatamento na mata atlântica: uma análise econômica. 2006. 83 p. Dissertação (Mestrado em Ciências Econômicas) Universidade Federal do Rio de Janeiro, Rio de Janeiro, 2006.

PINHEIRO, R. J. B.; DIAS, R. D. Mapeamento geotécnico da formação Rosário do Sul na região metropolitana de Porto Alegre. Instituto Geológico, volume especial, São Paulo, 1995.

RIBEIRO, M. C.; METZGER, J. P.; MARTENSEN, A. C.; PONZONI, F. J.; HIROTA, M. M. The Brazilian Atlantic Forest: How much is left, and how is the remaining forest distributed: Implications for conservation. Biological Conservation, v. 142, n. 6, p. 11411153, 2009.

SANTOS, R. C. M. Mata Atlântica: características, biodiversidade e a história de um dos biomas de maior prioridade para conservação e preservação de seus ecossistemas. 2010. 31 p. Trabalho de Conclusão de Curso (Graduação em Ciências Biológicas) - Centro Universitário Metodista Izabel Hendrix, Belo Horizonte, MG, 2010.

SILVEIRA, D. S. D. A propriedade agrária e suas funções sociais. In: Silveira, D. S. D. e Xavier, F. S. (Orgs). O Direito Agrário em debate. Livraria do Advogado, Porto Alegre, Brasil, 1998. 333 p.

SOS MATA ATALÂNTICA. Relatório Anual 2014. Available in: https://www.sosma.org.br/link/relatorio_anual_sosm a_2014/index.html. Accessed in: 12 maio 2016.

TRENTIN, C. B.; SALDANHA, D. L.; FONSECA, E. L. Influência da sazonalidade dos teores de carbono em áreas de vegetação campestre natural no Bioma Pampa. Geografia, v. 40, n. 2, p. 259-267, mai./ago. 2015. 